MP3-161 前立腺澏に対するヨード (1-125) シー ド線源を用いた小線源治療の経験

\section{国立国際医療センター泌尿器科1), 国立国際医療セン} ター放射線科2)，横須賀共済病院泌尿器科 ${ }^{3)}$

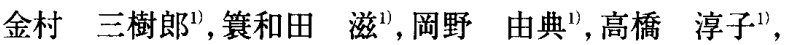

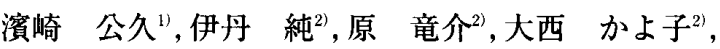
岸 洋一 ${ }^{31}$

当院では平成 16 年 4 月よりヨード 125 シード線源を永久挿入す る前立腺癌治療を開始し、9月までに 21 例経験した。治療の適応は 臨床病期 B で、前立腺体積が $40 \mathrm{cc}$ 以下を原則とした。診断確定から 治療までの待機期間があった例が多く、17 例になんらかのホルモン 療法が施行されていた。外照射を併用した症例は2例であった。3 泊 4 日の入院とし、治療前日中央手術室で麻醉科により硬膜外力 テーテルを挿入し、治療は放射線治療棟内の専用の手術室で施行し た。単独療法では平均 65 個の、外照射併用療法では平均 40 個の シード線源が留置された。Applicator 挿入開始から小線源の挿入終 了までに要した時間は 58-150 分であり、最近では 60 分程度に なっている。術中に膀胱内に線源脱落したものが 2 例あった。Postplanning での V100は $53.1 一 98.5 \%$ 、平均 $82.7 \%$ であった。骨盤腔に 線源が移動したもの5例、肺野に移動していたもの 2 例あった。移 動による臨床症状は認めなかった。軽度の血尿、排尿困難を認める 症例はあったが、尿閉や尿失禁、発熱例はなく、重篤な合併症は現 在のところ認めていない。予定入院期間が延長した例もなかった。 ヨード (I-125) シード線源を用いた小線源治療は比較的安全な治療 であると思われる。更に症例を重ねて検討する予定である。

\section{MP3-162 当院での一時刺入型高線量率小線源痖}

大阪医科大学医学部泌尿器科学教室 ${ }^{11}$, 大阪医科大学医 学部放射線学教室 ${ }^{2}$

木山 賢”, 東 治人 ${ }^{11}$, 坂元 武 ${ }^{1}$, 丸山 榮勲"

右梅 貴信 ${ }^{1)}$, 上田 陽彦 ${ }^{11}$, 勝岡 洋治 ${ }^{1)}$, 辰巳 智章 ${ }^{21}$,

猪俣 泰典 ${ }^{2)}$, 楢林 勇 $^{2)}$

前立腺癌に対する小線源療法は手術と同等の効果を持つ可能 性のある治療手段として注目されているが、当院では一時刺入 型の高線量率小線源療法を 2002 年 4 月より導入している。今 回は現在までの治療概要、治療成績について報告する。2002 年 4 月から 2004 年 9 月までの期間で 20 名の前立腺癌患者に 小線源療法が施行された。大部分は $18 \mathrm{~Gy}$ の小線源療法に加え $40 \mathrm{~Gy}$ の外照射が施行された。前立腺容積が $40 \mathrm{ml}$ 以上の患者 には neo-adjuvant therapy としてTAB (total androgen blockade) が施行された。観察期間は 7〜84ケ月であり患者の 年齢は 55〜79 歳であった。病期は T2a，T2b，T3，T4でいず れも遠隔転移のない症例であった。グリーソンスコアーは 4 9 であり加療前の PSA 值は 4.6 69 であった。加療後 3 ケ月の PSA 值はすべての患者において正常化し観察期間中に再発を 認める例はなかった。合併症として頻尿、残尿感、切迫性尿失 禁、排尿困難、下瘌等を認めたがいずれの症例でも数週間で軽 快している。これらの結果は一時刺入型高線量率小線源療法の 効果と安全性を示すものと思われ今後の症例の積み重ねによ りさらなる好成績を期待できるものと考えられた。

\section{MP3-163 前立腺癌に対する高線異率組機内照射 の経験}

\section{独立行政法人国立病院機構大阪医療センター䎵尿器科"', 独立行政法人国立病院機構大阪医瘄センター放射線科2， 市立豊中病院放射線科 ${ }^{3}$}

高橋 徹 ${ }^{11}$, 野原 隆弘 ${ }^{1}$, 河嶋 厚成 ${ }^{11}$, 北村 雅哉1), 赤井 秀行 ${ }^{11}$, 岡 聖次 ${ }^{1)}$, 吉田 謙 ${ }^{21}$, 能勢 隆之 ${ }^{31}$

【はじめに】当院では 2001 年より限局性もしくは局所進行性前立腺㿑 に対して一時刺入法による高線量率組織内照射 (HDR-ISBT) を開始 し、これまでに 22 例を経験したので報告する。(対象と方法】年齢は 60-85 歳 (中央值 71.5 歳)、観察期間 2-42 ケ月 (中央値 8.5 ケ月)、 臨床病期は T1c 5 例、T2a 2 例、T2b 6 例、T3a 4 例、T3b 5 例 (UICC 1997) で、生検前 PSA は $5.3-269 \mathrm{ng} / \mathrm{ml}$ (中央值 $20.55 \mathrm{ng} / \mathrm{ml}$ ) であっ た。全例に MAB 療法を施行し PSA 值が nadirになった時点で組織 内照射を行った。方法は、月曜午前に腰椎もしくは硬膜外麻酔下にテ ンプレートを使用し TRUSガイド下に治療用アプリケータを経会陰 的に挿入。原則として同日夕に 1 回、翌日より金曜までの 4 日間に 2 回ずつ計 9 回、1 回 $6 \mathrm{~Gy}$ で総線量 $54 \mathrm{~Gy}$ 照射。照射後ホルモン治療は 中止し経過観察とした。結果と結論】治療に伴う重篤な有害事象はな かったが、膀腅刺激症状、直腸出血などがみられた。臨床的再燃が 1 例、PSA 再燃が 2 例であった。今後も長期的予後に関する経過観察が 必要である。なお、本治療法の欠点は治療期間中の行動制限であるが、 われわれは、アプリケー夕留置中の体外に露出している部分を最小限 にするなどの工夫を加えることで、最近の症例では挿入翌日より歩行 も可能となり比較的苦痛の少ないものとなっている。

\section{MP3-164 前立腺癌永久括入密封小線源㽷法の ローディング法による比較}

昭和大学医学部泌尿器科", クイーンズメディカルセン タ-2), 昭和大学横浜市北部病院泌尿器科 ${ }^{3)}$

森田 將 ${ }^{1)}$, レダラー ジョン ${ }^{2)}$, 首藤 直樹 ${ }^{1}$,

冨士 幸藏"), 深貝 隆志 ${ }^{11}$, 島田 誠3), 吉田 英機1)

【目的】前立腺癌永久扦入密封小線源治療の 3 種のロー ディング法 (A ; Pre-loaded needle, B ; Rapid strand, C ; Mick applicator）に関して比較検討した。方法】2004 年 6 月までに 507 例の限局性前立腺癌患者に対して密封 小線源永久挿入治療を施行した。今回、2002 年に施術し た 60 例に関して検討した。【結果】A，Bはほほ同体積の 前立腺癌では $\mathrm{C}$ と比較して有意に手術時間が短かった。 手術終了時の XPでは肉眼的には Bが最も線源の変位 が少なく planning 通りの留置が行われたように思われ たが、術後の CT dosimetryでのパラメーターに関して は $\mathrm{A}, \mathrm{B}, \mathrm{C}$ で有意差のない結果であった。線源の migrationは、A，C間で有意差は認められなかった。【考察】大 きな前立腺体積に対して $\mathrm{A}$ ，B を用いて手術する事は手 術時間短縮の面から有効と思われた。Bは、seed migration が少なく、特に小さい前立腺体積の症例の場合有効 であると考えられた。スペーサー認可の問題から A， B は日本では現在使用出来ないが、近い将来認可される可 能性もあり、各器具の特徴に関しての認識が必要と思わ れた。 